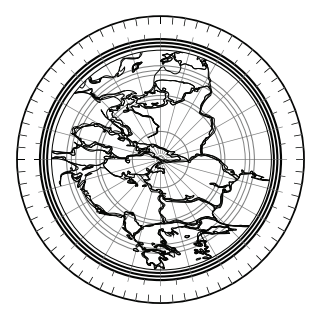

Sprawy Narodowościowe: Seria nowa, 2021(53), Article 2584

\title{
The Last Citizen of the Grand Duchy of Lithuania: The Editor Ludwik Abramowicz (1879-1939) and the Idea of Krajowość
}

DOI: https://doi.org/10.11649/sn.2584

\author{
Aliaksandr Smalianchuk \\ Institute of Slavic Studies, Polish Academy of Sciences \\ https://orcid.org/0000-0002-1827-5083 \\ e-mail: aleksander.smalianchuk@ispan.waw.pl
}

\begin{abstract}
Ludwik Abramowicz was one of the main ideologists of the idea of krajowość in its liberal-democratic version. He defended its principles even in the interwar period, when Poland was dominated by the policy of assimilation of national minorities and relations with Lithuania had the character of a cold war. Thanks to Abramowicz, Przegląd Wileński [Vilnius Review] (1921-1938) became the last bastion of the idea of krajowość, actively popularising it in the public life of the Vilnius Region. Abramowicz unwaveringly defended the idea of the political independence of the Belarusian-Lithuanian Lands and the decision of its future by the representatives of all indigenous nations. Abramowicz's life and work, his publications in Przegląd Wileński prove that against all political and national-cultural realities, the idea of krajowość as an idea of harmonious coexistence of the nations of the historical Lithuania was popular and found new supporters.
\end{abstract}

Keywords: national movements at the beginning of the 20th century; national idea; tolerance; Lithuanian Poles; historical Lithuania; Ludwik Abramowicz; Przegląd Wileński

This work was supported by the Polish Ministry of Education and Science.

No competing interests have been declared.

Publisher: Institute of Slavic Studies, Polish Academy of Sciences.

This is an Open Access article distributed under the terms of the Creative Commons Attribution 3.0 PL License (creativecommons.org/licenses/by/3.0/pl/), which permits redistribution, commercial and non-commercial, provided that the article is properly cited. (c) The Author 2021. 


\section{Introduction: Abramowicz and Krajowość}

Ludwik Abramowicz died on 9 March 1939. Already on the next day, an obituary appeared, written by Stanisław Mackiewicz, editor of Słowo [Word], a Vilnius daily. He admitted that Abramowicz had been his ideological and even personal opponent, totally devoted to the idea of krajowość (Kraj ideology) but at the same time he praised Abramowicz's journalistic activity:

He remained a Krajowiec [Kraj supporter] under the slogan contra spem spero. ${ }^{1}$ Indeed, the Treaty of Riga, the existence of the independent Lithuanian republic, and finally Polish internal policy were slowly blighting all chances of implementing this programme, even if only roughly. But Ludwik Abramowicz continued to publish his Przeglad Wileński [Vilnius Review]. Others left him, they engaged in jobs and positions. Today, at the time of his funeral, even the group of "democrats", namely Krajowcy-opportunists, is quite small. We valued Mr Ludwik Abramowicz precisely because he not only was a man of principles but did not sell his principles for an executive suite or benefits. Once again, let us say to this ideological opponent: May he rest in peace! (Mackiewicz, 1939, p. 1)

Who was Ludwik Abramowicz, this "man of principles", so heartily described even by his political opponents? And why did he deserve such a high opinion of one of the most famous columnists of the Second Polish Republic? I will address these questions, applying a biographical approach, i.e. the method where the subject matter is life of an individual, framed within a stream of narratives. Here, my main sources to reconstruct and analyse Abramowicz's life were his personal documents and publications, as well as archival materials from the collections of the Lithuanian Academy of Sciences and the diary of Abramowicz's close friend, Michał Römer.

Ludwik Abramowicz was born on 5 July 1879 in Moscow. His father, Jan, was a lawyer, while his mother was Maria née Mroczkowska. Abramowicz was their third son: he had older brothers, Marian and Witold. From the beginning, Abramowicz's life was connected with Belarusian lands, since his parents, although living in Moscow, kept in touch with their relatives from Belarusian governorates. Ludwik spent his early years in the Belarusian-Lithuanian Lands, which were then suffering under the oppressive policy initiated by the infamous general Mikhail Murav'ëv Vilenskiĭ and continued by his successors. Abramowicz graduated from secondary school, presumably in Minsk, and from there went on to study at Moscow University. He continued his studies at Kharkiv University and finally left for Paris, France. It is where his journalistic and social activities began. According to Maria Nekanda-Trepka, a researcher and relative, it was in Paris that the journalist with socialist views was born who began to fight against nationalism (Nekanda-Trepka, 2005, p. 50).

At the beginning of the twentieth century, Abramowicz moved to Galicia, where he studied at the Faculty of History of the Jagiellonian University and continued his journal-

1 I believe against hope (Latin). 
istic activity. At that time, he started to collaborate with the organisations of the Polish national movement and stayed in touch with Polish military organisations in Galicia; his older brothers belonged to the Polish Socialist Party.

In 1904, Abramowicz went to Vilnius, the city he would be connected with for the rest of his life. It was a time when the life in the Romanov Empire started to change. In the far East, Russia was defeated by Japan in the ongoing war (1904-1905), while in its European parts, social and national upheaval was growing. The example of the latter was the so-called Autonomists Club (Klub Autonomistów), established in Vilnius and consisting of representatives of the local Polish, Lithuanian and Belarusian communities. Abramowicz was one of the representatives of the Polish community. The uniting principle here was the conviction that the lands of the former Grand Duchy of Lithuania should be autonomous in the future (Miknys, 2001, pp. 97-113).

Going forward, the Russian Revolution of 1905-1907 contributed to liberal and democratic changes in the country. The most important change was the gradual transformation of the Romanov Empire into a monarchy that was restricted by popular representation: the State Duma and the reformed State Council. Thus, these were the new political circumstances of Abramowicz's activities. In Vilnius, Ludwik Abramowicz met with Michał Römer (1880-1945), the future chief "architect" of the idea of krajowość in its democratic version. Having graduated from the Imperial School of Jurisprudence in St Petersburg and having received his law degree there, Römer continued his studies at the École Libre des Sciences Politiques in Paris. In the summer of 1905, he came to Vilnius only for holiday but never returned to Paris. The atmosphere of change took and prompted him to start his own publishing project. The idea was to publish a liberal-democratic daily newspaper. Abramowicz offered his services to the newly formed editorial team.

The meeting with Römer resulted in establishing a friendly relation that lasted until the end of Abramowicz's life. There was spiritual closeness between the two of them, they both were faithful to the idea of krajowość. However, their understandings of krajowość were not always the same, which resulted in ideological conflicts. After all, the friendly relation between them continued even when Römer and Abramowicz were separated by the state border between Poland and Lithuania.

On 15 (28) February 1906, ${ }^{2}$ the first issue of Gazeta Wileńska [Vilnius Gazette] was published. The magazine became the platform for the liberal-democratic circles of Belarus and Lithuania. ${ }^{3}$ However, the main achievement was the development of the most original concept of Polish political thought at the beginning of the twentieth century, namely the ideology of krajowość in its democratic version (Solak, 2004, p. 73).

\footnotetext{
2 In the early twentieth century the Russian Empire still used the Julian calendar. The date in parentheses is the equivalent according to the Gregorian calendar.

3 Gazeta Wileńska was published only for half a year. It was closed in July 1906 due to lawsuits and financial problems.
} 


\section{Krajowość as an Alternative Project}

The idea of krajowość appeared among Lithuanian Poles as a response to the rising nationalisms, especially in the context of the demands of the Lithuanian and Belarusian national movements. ${ }^{4}$ Krajowość provided an opportunity for contact between representatives of different national movements of the historical Lithuania. Moreover, it was supported by the democratic circles of the Belarusian and Lithuanian movements. Their representatives even promoted the idea of krajowość, understanding that it broadened national and religious tolerance, favoured the unification of the nations of the Belarusian-Lithuanian Lands in the struggle against the policy of the Russian Empire, and could support the national aspirations of individual nations.

The main objective of the Krajowcy (Kraj supporters, literally meaning Fellow Countrymen) was always the unity and indivisibility of the Belarusian-Lithuanian Lands, their separate status and in the larger picture: autonomy. In the editorial, published in the first issue of Gazeta Wileńska Römer wrote:

In defining our standpoint we must be guided by the Kraj needs and in them seek the starting point for all political, social, and cultural actions. For this reason, we reject the standpoint of the so-called "kresy" [borderlands], which treats our countries [...] as someone else's satellites [...]. ([Römer], 1906)

Thus, Römer regarded the Belarusian-Lithuanian Lands as a historical continuation of the former Grand Duchy of Lithuania. The memory of it was an important element in the consciousness of the Krajowcy, who sometimes called themselves the last citizens of the Grand Duchy. In the article quoted above, Römer continued:

We, citizens of Lithuania and Belarus, cannot be Polish colonists. In this scope of national citizenship, that is, in political, social, and economic terms, Lithuania and Belarus are our homelands. However, we are sons of the Polish nation only in the cultural and national field, and we will not and do not want to relinquish this kinship of ours. ([Römer], 1906)

What did that exactly mean?

The historical studies made to date (Bardach, 1988; Januszkiewicz-Jurkiewicz, 2010; Jurkiewicz, 1999; Miknys, 2000; Sawicki, 1998; Smalianchuk, 2004, 2017, 2018; Szpoper, 2009) understand krajowość as a certain alternative to the ethnocultural variant of national ideology dominant in the region of Lithuania, Belarus, Ukraine and Poland. Ideologues of krajowość, such as already known to the reader Michał Römer or Ludwik Abramowicz, but also Raman Skirmunt, Konstancja Skirmuntt and Bolesław Jałowiecki)

4 Belarusian politicians were particularly active in supporting the idea of krajowość, as evidenced by Skirmunt's joining the Belarusian movement at the end of 1916. Even more significant was the cooperation of the Vilnius circle gathered around the Nasha Niva [Our Land] newspaper with the Krajowcy of the democratic current, including Abramowicz. 
represented these Lithuanian Poles who cultivated the tradition of political and cultural otherness of the lands of the former Grand Duchy of Lithuania, and they considered the historical Lithuania (i.e. the lands of the former Grand Duchy of Lithuania after the Union of Lublin in 1569, so the contemporary Lithuanian and Belarusian lands) rather than historical Poland to be their homeland.

The concept of nation as a political or social category was at the foundation of krajowość. According to the ideologists of krajowość, anyone who considered themselves to be a Kraj citizen and was a patriot of the historical Lithuania belonged to the Kraj nation, while ethnic and cultural otherness was a secondary matter and should not interfere with the national political entity. Yet, at the beginning of the twentieth century there were different variants of the idea of krajowość, and there was a lively discussion among the Krajowcy. On the social plane, two currents of the ideology of krajowość can be distinguished: the democratic one, with Römer as the main representative, and the conservative one, in the creation of which the publications of Raman Skirmunt (1868-1939) played a great role. However, even within both currents there was no unanimity of views.

In 1906, the aforementioned Gazeta Wilenska became the centre of the Krajowcy. For Abramowicz it was an opportunity to reveal his talent as a journalist. Römer recollected: "Ludwik proved to be a good journalist, he was one of the outstanding forces in the paper. In particular, his feature articles were scathing, he wrote them under the pseudonym of Licz" (Römer, 2017-2019, p. 26). The main task of the newspaper was to favour the harmonious coexistence of various national and cultural elements on the foundation of the common Kraj citizenship.

After Gazeta Wileńska ceased to exist, Abramowicz was invited by the editor Czesław Jankowski ${ }^{5}$ of Kurier Litewski [Lithuanian Courier], the then most popular daily paper in the country, to join their team. Kurier Litewski also supported krajowość but in its more conservative version. Soon, Abramowicz became one of the leading journalists of Kurier: he was commissioned to report on the State Duma sessions, in which representatives of Lithuanian Poles, including the Krajowcy deputies from Belarus and Lithuania, played an active role. Abramowicz left Kurier in June of 1911, after it merged with Goniec Codzienny [Daily Messenger].

In November the same year, however, together with Michat Römer he established another Kraj-oriented magazine: the weekly Przegląd Wileński [Vilnius Review] (1911-1915). Already in the first issue, he wrote that that Przeglad Wileński "will be based on the Kraj citizenship, recognising the Lithuanian-Belarusian Lands as a separate country, united by common interests, constituting a territorial entity and inhabited by nationalities that have

\footnotetext{
5 Later, Abramowicz mentioned editor Jankowski with gratitude: "I already had quite clearly crystallised political and social views, to which, in general terms, I have remained faithful to this day. However, I had no writing practice and I did not have the slightest idea about the journalistic technique. At that time, I benefited a lot from the professional advice of one of the most talented editors, although I could not get used to his requirements for the confidence and liveliness of writing, which he demanded from his associates. That is why he kept telling me that I would never be a real journalist because I lacked a bent for journalism" (L. A., 1929, p. 8).
} 
equal rights to decide about themselves and the future of the country" (Abramowicz, 1911). Thus, the editor confirmed his intention to continue the tradition of Gazeta Wileńska.

Przeglad Wileński paid much attention to the question of nationalism. The Lithuanian national movement and Polish-Lithuanian conflict were always an agenda. Despite the great scale of Polish-Lithuanian conflict Abramowicz, together with Römer, were convinced that democratisation processes would pave the way for the mutual agreement. Especially since Krajowcy believed that common interest of former Grand Duchy of Lithuania territories was more important than interests of single local nations and national groups. This also concerned Lithuanian Poles. Abramowicz argued that they are the local matter, strongly rooted in the region that has been and will always be their Motherland (Abramowicz, 1913a).

From his writing in Przeglad it becomes clear that at the time Abramowicz understood the Belarusian-Lithuanian Lands as a kind of confederation of independent and equal national communities, and in his opinion each of them had the right to its own national and cultural development. Thus, krajowość was for him a method of coexistence of the various nations of the historical Lithuania with the predominance of tolerance in national and religious relations, and a means to preserve the territorial unity of the Belarusian-Lithuanian Lands. With reference to this coexistence, he was concerned for the right of the Polish community to develop its own culture (Abramowicz, 1913a).

But what Michał Römer saw lurking in his colleague's stance was a hidden Polish nationalism. Unlike Abramowicz, he understood the Belarusian-Lithuanian Lands as a unified and indivisible entirety, pervaded with the feeling of national patriotism and independent of any division into individual nations. ${ }^{6}$ In his sociopolitical activity, Römer, as he himself emphasised in his architecture-oriented metaphor, strove to build a single "civic" building rather than a series of national cottages. ${ }^{7}$ For some time their paths diverged. Thus, he left Przeglą Wileński and began cooperation with Kurier Krajowy [Country Courier], a periodical published in Polish and Belarusian, supervised by Belarusian activists, brothers Ivan Lutskevich (1881-1919) and Anton Lutskevich (1884-1942).

This enterprise was unusual: together with a weekly in the Polish language (Kurier Krajowy, 1912-1914), the Lutskevich brothers published also a daily newspaper in the Russian language (Vecherniaia Gazeta [Evening Gazette], 1912-1915) (Smalianchuk, 2004, pp. 267, 269 et al.). In the former case, they appeared as Polish democrats, while in the latter - as Russian democrats. In the pages of both magazines the term "citizen of the Kraj" was present: one of the basic terms in the concept of the Kraj political nation. The authors and correspondents proved that the most important problems for the Kraj should be solved taking into consideration the interests of all the nations of Belarus and Lithuania, so they condemned Great-Russian chauvinism, and were in favour of fight against signs of nationalism among Belarusians, Lithuanians and other nations of the former Grand Duchy.

6 Römer, Dziennik, vol. 2; f. 252, The Wróblewski Library of the Lithuanian Academy of Sciences (hereafter BiWANL).

7 Römer, Dziennik, vol. 2; f. 89, BiWANL. See also: Miknis, 2008, pp. 236-260. 


\section{Abramowicz and Krajowość vis-à-vis the Belarusian National Movement}

However, a certain pragmatism of the Belarusian Krajowcy should be noted. For example, they actively used the concept of a common historical Homeland, promoted the cooperation of democratic elements of various national movements, spread the idea of tolerance but at the same time ignored the claim of the common roots of Belarusians, Lithuanians, and Poles, which was important for krajowość. While propagating elements of the idea of krajowość, they remained Belarusians. Krajowość allowed them to expand the social and cultural space of the Belarusian revival movement and establish contacts with both activists of other national movements and representatives of the local aristocracy and landowners, who positively treated the cultural activity of the adherents of the Belarusian Revival and supported it (e.g. Maria Magdalena Radziwiłł, Edward Woyniłłowicz, Raman Skirmunt).

Also, the idea of krajowość was an important factor in the nation-building process as it could become a platform for overcoming the religious division among the Belarusians and could be a means of strengthening the position of the Belarusian nation in the national, cultural and sociopolitical life of the Lands. For example, the agitation regarding the necessity of an agreement between Poles and Belarusians was explained by the lack of prospects for the development of the Polish movement in the Belarusian-Lithuanian Lands.

The leaders of the Belarusian movement were convinced that Lithuanian and Belarusian Poles were the descendants of Polonised Lithuanians and Belarusians, and therefore demanded that those people work to develop the consciousness and culture of Belarusians and Lithuanians. A specific "Belarusian deviation" was clearly visible in the krajowość of the activists who were gathered around Nasha Niva [Our Land]. This "deviation" provoked a discussion among the Krajowcy. The main opponent of the Belarusian Krajowcy was exactly Ludwik Abramowicz. In a number of articles in Przeglad Wileński he fiercely criticised the position of the editors of Kurier Krajowy and Vecherniaia Gazeta and defended the right of Lithuanian Poles to develop Polish culture.

However, the Belarusian Krajowcy understood Abramowicz's standpoint as an aspiration to continue the policy of Polonisation. The discussion was sometimes very heated and mutual accusations of nationalism were often made. In the winter of 1913, the editorial in Przeglad stated that "a group of Poles-doctrinaires of the idea of krajowość" that was publishing Kurier Krajowy had come under the influence of Lithuanian and Belarusian activists (Abramowicz, 1913b). In another publication, Abramowicz even accused the editors of Vecherniaia Gazeta of hatred towards Poles and expressed his doubt in the honesty of the newspaper's concern for Belarusian culture. According to him, the publication of this liberal magazine in the Russian language facilitated further Russification (Abramowicz, 1912). This proves a certain unity among Krajowcy, even if they argued quite sharply within the group. For example, Abramowicz knew about 
this specific "Belarusian masquerade", with which the Vilnius Freemasonry was directly related, but even in situations of sharp discussions with Belarusians he did not reveal the secrets of the two periodicals.

Römer, who criticised both sides of the debate, reacted more harshly to the publications of his Polish colleagues. In his Dziennik, considering the position of Abramowicz and his magazine, Römer wrote that these Polish "democrats" demonstrated disdain for weaker nations. ${ }^{8}$

However, beyond the boundaries of the press scuffle, Krajowcy stayed in touch with each other as they were united by their concern for the future of the Belarusian-Lithuanian Lands and by the consciousness that tsarism remained their main enemy. The future showed that supporters of the same views disputed with each other.

\section{The War: Abramowicz and the Independence Issue}

Ludwik Abramowicz left Przeglad Wileński in February 1914. The newspaper modestly reported it as his moving to "the wider arena of Warsaw" ("Od redakcji", 1914). It is possible that Abramowicz's departure from the newspaper he had founded was conditioned by certain financial troubles with which he grappled all the time: let's remind the reader about the fate of ephemerical Gazeta Wileńska, pervaded by the same troubles. At the beginning of 1914, he left for Warsaw, where he continued his journalistic activities and actively cooperated with circles of supporters of Polish independence.

According to Zbigniew Solak, Abramowicz came to Warsaw to run the newspaper Strażnica [Watchtower]. He managed to publish only two issues, which were impounded by the censorship. Then, the newspaper was closed down (Solak, 2004, p. 233). But Abramowicz was not left without a job. On the eve of the outbreak of the First World War, he replaced Wincenty Rzymowski as the editor of Prawda [Truth], a Warsaw newspaper that was established by Aleksander Świętochowski (1839-1938), the foremost Polish ideologist of the positivist doctrine (Solak, 2004, p. 233).

While working in Warsaw, Abramowicz did not break off contacts with Vilnius. In November 1914, he forced his way through the front to investigate the status of the action of Pitsudski's Legions. He returned to Vilnius via Vienna and Bucharest and talked about the Legions and the fight for the independence of Poland with Lithuanian Poles and Krajowcy. As he later recalled, the mood in Vilnius was Russophile. Almost no one was interested in information he brought from Warsaw, and there was no enthusiasm for Polish pro-independence slogans (L. A., 1928b).

In the autumn of 1915, after the victorious German operation on the eastern front and the occupation of Congress Poland and a large part of the lands of the historical Lithuania, the supporters of the independence of the Belarusian-Lithuanian Lands became more active.

8 Römer, Dziennik, vol. 4; f. 301, 304, BiWANL. 
In one of his articles, Abramowicz, who at that time worked in the editorial section of Myśl Polska [Polish Thought] newspaper, returned to the problem of the homeland of Lithuanian Poles and stated that

Polishness in Lithuania is absolutely independent of the slogans coming from Warsaw. It is a separate local Polishness: whether it is in its best or vegetates - this is determined by local factors. Any return of Lithuanian Poles to the ethnographic Poland is out of the question because they all did not leave that place, and only Lithuania is a country with which they are ethnographically attached. (B. H., 1915)

Thus, he remained truthful to the idea of krajowość.

The activation of the Krajowcy in Vilnius resulted in the formation of the Provisional Council of the Confederation of the Grand Duchy of Lithuania (Tymczasowa Rada Konfederacji Wielkiego Księstwa Litewskiego) at the end of 1915, which advocated the state independence of the historical Lithuania in alliance with Germany and Austria-Hungary. The demand for the autonomy of the Kraj, which was natural for the Krajowcy, changed into the idea of the state independence of the Belarusian and Lithuanian lands. The newly formed state was supposed to guarantee all its nations the right to free cultural development. The Provisional Council unified activists of various national movements, and the initiators of its creation were Belarusians, such as Ivan Lutskevich. However, it did not stand the test of time. The exacerbated relations between the various nationalities, especially Poles and Lithuanians, further heated by the German occupation administration, ruined this project (Ponarski, 1998, pp. 58-67; Smalianchuk, 2004, pp. 312-315).

Yet, we see Abramowicz as one of the initiators of the establishment of the Grand Duchy of Lithuania Association (Koło Wielkiego Księstwa Litewskiego) in Warsaw, whose members discussed the future of the Grand Duchy of Lithuania and the Kingdom of Poland in the event of a German victory (Römer, 2017-2018, vol. 3, p. 93; entry dated 9 May 1916). Abramowicz remained an advocate of the indivisibility of the Belarusian-Lithuanian Lands (Römer, 2017-2018, vol. 3, p. 146; entry dated 9 July 1916). At the same time, he worked for the Polish Statehood League (Liga Państwowości Polskiej), which was oriented towards Austria-Hungary in the matter of Poland's independence. Abramowicz performed the duties of the secretary of the League and edited the re-established Strażnica (Römer, 2017-2018, vol. 3, p. 120; entry dated 13 June 1916). He actively participated in the process of revival of the Polish statehood. However, the question of the historical Lithuania's future always came to the front in his activities.

In the years 1917-1918, he was active in various organisations that represented the Kingdom of Poland and often acted as an expert on Lithuanian affairs. He even began to learn the Lithuanian language. Eventually, Abramowicz got the position of the Lithuanian-Belarusian affairs officer at the Provisional Council of State (Tymczasowa Rada Stanu), which was created by German and Austro-Hungarian authorities in January of 1917 at the territory of former Congress Poland. This was the time when he prepared for print 
a selection of documents concerning the contacts of the activists of national movements of the historical Lithuania with the outside world (L. A., 1918).

As an officer of the Provisional Council of State, in the spring of 1918 Abramowicz went to Vilnius, which was still occupied by the German troops, and stayed there after they left. Also, he kept a close eye on the situation in Minsk. For this purpose he started to exchange letters with one of the leaders of the Polish Council of the Minsk Lands (Rada Polska Ziemi Mińskiej), Edmund Iwaszkiewicz.' Between May and August of 1918, the latter regularly informed him about the activity of the Council of Belarusian People's Republic. In his letters he often mentioned the names of lazep Varonka and Raman Skirmunt, which proves that he backed up the Belarusian movement.

When in July 1920 Vilnius was occupied by the Bolsheviks, Abramowicz acted as a guardian of the property of the re-established Vilnius University and even under the threat of death he managed to protect it from plunder. The defence of the university was the defence of the institution crucial for the culture and development of the state. The university departments, the rich libraries and the astronomical observatory were saved. Later, the first rector of Stefan Batory University, Professor Michat Siedlecki, thanked Abramowicz sincerely on behalf of the students and lecturers (Nekanda-Trepka, 2005, p. 52).

The moment came that the advocate of the indivisibility of the historical Lithuania had to watch the collapse of the idea of krajowość, to which Lithuanian politicians directly contributed as they were striving for an independent Lithuanian state within the borders of the ethnographic Lithuania, also making claim to Vilnius and the Vilnius Region. Likewise, the Bolshevik Russia's policy towards the Belarusian-Lithuanian Lands was expansionist. Moreover, the claims to these lands were also made by Polish National Democrats.

\section{"Free with the free, equal with the equal". Krajowość in the Interwar Period: Rejected Chance}

The fates of the ideologists of krajowość after the political collapse of the historical Lithuania were different. Raman Skirmunt ended the Belarusian period of his political life in the summer of 1919 and after the Treaty of Riga, which he tried to prevent from being ratified, he focused on the problems of his native Polesia. His attempts to return to active political life were successful as late as in 1930, when he was elected senator from the list of the Non-Partisan Bloc for Cooperation with the Government (Bezpartyjny Blok Współpracy z Rządem, BBWR). Michał Römer moved to Kaunas and took an active part in consolidating the Lithuanian statehood, at the same time striving to take care of the relations between Poland and Lithuania. Anton Lutskevich remained an active member of the Belarusian movement, combining political activity with cultural work.

9 Abramowicz, Fond 79-31, BIWANL; Gierowska-Kałłaur, 2007, pp. 35-66. 
All of them, to a greater or lesser extent, remained faithful to the idea of krajowość but for the most of the former Krajowcy it ceased to be an issue of public life. And only Ludwik Abramowicz continued to defend its principles, ignoring the domination of ethno-cultural nationalism in the region. He supported and promoted krajowość in the Vilnius press, i.e. in Nasz Kraj [Our Country] (1919), Gazeta Krajowa [Country Gazette] (1920-1922) and Przeglad Wileński (1921-1938), There, in the editorial of the first Gazeta Krajowa issue Abramowicz reaffirmed his krajowość views and spoke out against racial, social and national intolerance. As for the future of Belarusian-Lithuanian Lands, he had high hopes with a constituent assembly that would be elected by universal suffrage (Abramowicz, 1920, p. 1).

The first issue of the re-established Przeglad Wileński was published on 1 November 1921. Vilnius was then the capital of the so-called Central Lithuania. Incidentally, Abramowicz supported general Lucjan Żeligowski's "mutiny" and the seizure of Vilnius by Polish army (October 1920) because he saw in these events a chance for the rebirth of the idea of krajowość with the help of Poland, all the more so because the government of Central Lithuania included former supporters of krajowość and his brother, Witold Abramowicz, became the Minister of the Interior. However, Ludwik Abramowicz quite soon realised that the created quasi-state was for the Polish authorities only a cover for solving the territorial disputes with Lithuania. Nonetheless, he did not give up - he adopted the words from the well-known speech of Józef Pitsudski to the citizens of the former Grand Duchy of Lithuania as a characteristic motto of the resumed newspaper: "Free with the free, equal with the equal".

In the editorial in the first issue, Abramowicz stressed the topicality of the tasks which he had formulated for the pre-war Przeglad Wileński already in 1911. At that time, the editors promised to be in favour of "Kraj citizenship", stated that the Belarusian and Lithuanian lands were considered as a separate entity with different interests, and defended the right of all indigenous inhabitants to decide their own future. The editors were against all signs of chauvinism and intolerance. Ten years later, Abramowicz found that tsarist oppression had been replaced by Polish chauvinism. He described the situation in Central Lithuania, where "religious-national fanaticism" prevailed, as a mockery of the ideals of freedom, equality, and brotherhood. The editors promised to unite people who put the common interests of the country above the egoism of individual nations (Abramowicz, 1921, p. 1). This proves that Abramowicz remained faithful to his own understanding of krajowość. Yet, his concept of "building a few national cottages", to refer to Römer's metaphor, was more popular before the outbreak of the war. Once, in the pages of his Dziennik, Michat Römer compared him to a bison which had survived the mass extermination of this species during the Great War (Römer, 2017-2018, vol. 5, p. 593; entry dated 25 December 1928).

The hope for a renewal of the political part of the Kraj project evaporated in March 1932, with the League of Nations accepting the eastern borders of the Second Polish Republic. Thus, the aim of the magazine became to objectively and critically report on the most acute problems in the life of the Belarusian-Lithuanian Lands and to oppose the nationalist press. Representatives of national minorities regularly published in the pages of Przeglad Wileński, 
and although it was a Polish magazine they had a unique opportunity to inform the local community about their views on the peculiarities and system of Polish power in the Vilnius Region and on the problems of national life in interwar Poland. The editors and authors of the texts raised the acute problems of Belarusian and Lithuanian education, criticised the policy of Catholic proselytism and the expansion of the Polish language in churches in Belarusian towns, protested against unfounded accusations against Belarusian charitable, cultural and even religious organisations of carrying out pro-Soviet propaganda, condemned the economic oppression of local authorities against Belarusian and Lithuanian economic organisations, and described the Russification tendencies of the Neo-Union. The magazine reacted very sharply to the signs of antisemitism in Polish social and political life. ${ }^{10}$

In November 1923, recapitulating some of the results of the periodical's two-year existence, Abramowicz wrote that the primary task of Przeglad Wileński had become the fight against nationalism which was turning the Belarusian-Lithuanian Lands into "a testing ground for various centralist-unification experiments" (Abramowicz, 1923, p. 1). He also acknowledged the existence of Lithuanian and Belarusian nationalisms but claimed that they were defensive in nature. He emphasised that Przeglad Wileński had gathered a group of supporters of its programme and he expressed hope that the magazine's activity "must lead to the formulation of the Kraj programme as the only concept that may reconcile the divergent interests and aspirations of individual nationalities living in our country. As we are deeply convinced that the Kraj is a much more solid creation than the nation" (Abramowicz, 1923, p. 2). At the time, Abramowicz and Przeglad faced another challenge: the Second Polish Republic going towards Poland as a one-nation state, reflected in Dziennik Wileński [Vilnius Daily]. The newspaper, a press organ of the Endecja (the nationalist camp), became the main opponent of Przeglad. For its editors and authors, krajowość was a betrayal of national interests and for this reason Dziennik Wileński regularly accused Przeglad Wileński of being anti-Polish.

\section{The "Vilnius Question" and the Belarusian National Movement in Abramowicz's Interwar Activities}

Przeglad Wileński became a platform to raise various issues which were otherwise absent in the public space of the Second Polish Republic. In this respect, we can roughly distinguish Abramowicz's and Przeglaqd's concerns into those regarding questions connected to Lithuanian, Belarusian, Ukrainian and Jewish culture. Hence, it covered the entirety of the richness of the former Grand Duchy.

10 This results in the difficulty to write about Przegląd Wileński and its authors. They usually hid under pseudonyms or pen names, most of which have not been decoded so far. This mysteriousness is not difficult to explain. The province authorities, Archbishop Romuald Jałbrzykowski and the whole Vilnius curia regarded the standpoint of the newspaper and its editor as anti-Polish, with all the consequences that this entailed. One needed loyalty to certain ideas and civic valour to publish in Ludwik Abramowicz's magazine. 
Since the headquarters of the magazine was in Vilnius, the most urgent topic in the pages of Przeglad was relations with Lithuania. Abramowicz quite often returned to the "milestone" in these relations, namely, the "Vilnius question". After all, since 20 February 1922, it had not been resolved either by Żeligowski's "mutiny" or the decisions of the Sejm of Central Lithuania. In October 1928, the editor wrote about the importance of this "question" also for the development of Vilnius: "[...] as long as both sides do not abandon their implacable positions, as long as they strive for exclusive dominion - there can be no question of the permanent existence of Vilnius, of normal living conditions, of peaceful and creative work in our country" (L. A., 1928a, pp. 1-2).

Przeglad regularly informed its readers about the political and cultural life of Lithuania. It regularly reported on the Lithuanian latest publications, and published works or excerpts of works by famous Lithuanian writers translated into Polish. One of the experts on this issue was Michat Römer, Abramowicz's old friend, who in the interwar period sat on the Lithuanian Supreme Court and worked at the Vytautas Magnus University in Kaunas (see Römer, 1929a, 1929b, 1929c, 1929d, pp. 7-10, 1930, pp. 8-10). Römer also tried to find a way to the Polish-Lithuanian agreement. In spring 1934, in his article about the conflict between Lithuania and Germany regarding the status of Klaipeda, he wrote about "Baltic solidarity" and the importance of Poland's support for Lithuania's position (Römer, 1934, pp.1-4). The weekly also published declarations by Lithuanian organisations in Vilnius that were protesting against the policy of Polonisation, which in the second half of the 1920s even invaded the Roman Catholic Church in Poland (see Skarga Litwinów Wileńskich, 1928, pp. 2-4).

As well, the reports in Przeglad were full of sympathy for the cultural aspirations of the Belarusian movement: they supported its struggle against denationalisation and Polonisation. For example, in the spring of 1931, an article about various currents in the Belarusian movement was published in Przeglad. But the editors, maybe Abramowicz himself, did not refrain from a comment that left no room for illusions:

Both the autonomy and the satisfaction of Belarusian or Lithuanian national-cultural aspirations can only happen through concessions on the part of the authorities, dictated by necessity. And this necessity can only be brought about by the forces of individual national movements and the unanimity of the aspirations of the entire population of the country. (Bielski, 1931, p. 5)

The magazine often discussed the issue of the Belarusian language in the Catholic Church. Various authors, including activists of the Belarusian movement, wrote about the importance and momentousness of this issue, referring to earlier attempts to introduce the Belarusian language (Vigilans, 1930, pp.4-5). The tragedy of the population of Soviet Belarus remained an important topic for the editors of the magazine. Collectivisation and repression against the Belarusian intelligentsia were seen as an attack on the cultural and economic foundations of the independence of Belarus (for example: S-icz, 1934, pp. 3-5; W. S., 1931, pp. 5-7; 
"Za wschodnią ścianą", 1930, p. 2). The Belarusian issues were presented in Przegląd Wileński by Anton Lutskevich, Frantsishak Hrynkevich, Stanislaŭ Stankevich, lan Pazniak, Frantsishak Aliakhnovich, Uladzislaŭ Talochka, Adam Stankevich and others. Ludwik Abramowicz, Konstancja Skirmuntt and a number of other authors also wrote about Belarusians. The most interesting publications were those of Father Talochka and Anton Lutskevich as they contained both an analysis of current events and a certain retrospective.

Przeglaqd Wileński and its editor also fought against the signs of antisemitism in the politics of the local authorities (e.g. J. H., 1931, pp. 11-12; Kon, 1928, pp. 5-6), they published materials about the political feeling in Jewish society (Hal, 1929), about the problems of feeding Jewish colonists after the poor harvest of 1929 (Ż. A. T., 1929). The magazine regularly published overviews of the Jewish press.

Reviews of Ukrainian literature were also quite frequent, along with the publication of overviews of some titles. The dominant themes of "Ukrainian issues" in the pages of Przeglad were the development of Ukrainian culture and the fate of the Orthodox Church Union and its activists (e.g. Swiencickyj, 1930a, 1930b).

Despite all that, Abramowicz remained faithful to his most important idea. He wrote:

Nationalism, the intensity of which is now perhaps reaching its culmination point, blinds and obscures the prospects for the future. But it is clear and indisputable to anyone who has not been carried away by the surging tide of nationalist passion, who has not been stupefied by the exciting music of chauvinistic jazz-bands, that the time for disillusion will come, and that our present state, which can be characterised as bellum omnium contra omnes, ${ }^{11}$ cannot last forever. The day will come when the idea of krajowość will triumph because it alone is capable of untying the tangle of conflicts and antagonisms that has arisen as a result of the unbridled national egoisms that are constantly clashing. [...] In spite of the artificial borders which have divided our country, Lithuania and Belarus have not ceased to be one organism, and the torn parts of the country have continued to lean towards each other. None of these parts is strong enough to absorb and attract the others. But they all want to join together and create a common whole in new shapes - perhaps unconsciously - and will strive to do so contrary to any obstacles. Isn't it highly significant that both Lithuania and Belarus appear under the same sign - the Pahonia? (Abramowicz, 1925, p. 2)

The main direction of the activity of Przeglad Wileński was the promotion of krajowość. The idea of krajowość was presented as the most feasible option towards nationalism.

What changed, though, was the milieu where krajowość was discussed. In contrast to the pre-war times - when the propaganda of krajowość was accompanied by a discussion among the Krajowcy and representatives of the Polish, Lithuanian and Belarusian movements who were searching for an optimum variant of the idea of krajowość and striving to combine krajowość with the interests of individual nations - in the 1920s and 1930s the journalists of Słowo and Kurier Wileński [Vilnius Courier] became the main opponents of the concept of krajowość of Przeglad Wileński.

11 War of all against all (Latin). 
Stowo began to appear in 1922. It was changed by the editor Stanisław Mackiewicz, whose opinion on Abramowicz opened this article, into a real bastion of conservative thought, which also had a kind of its own "Kraj vision". Another position was occupied by Kurier Wileński (1923-1940), which reflected the feeling of the democratic circles of the Polish community in Vilnius. Its editor Kazimierz Okulicz (1923-1937) also belonged to the supporters of krajowość. In January 1928, the newspaper published a conceptual article entitled "Idea krajowości" [The Idea of Krajowość]. The author, using a Lithuanian pseudonym, understood krajowość as the territorial autonomy of the Belarusian-Lithuanian Lands within the borders of the Polish state. Even when speaking about the idea of reviving the Grand Duchy of Lithuania, he saw its future only in federation with Poland (Lit., 1928a, 1928b, 1928c, 1928d). Thus, in fact, it was krajowość about which Römer once said that some people say "krajowość" and think "the borderlands of the Most Serene Commonwealth of Poland" (Nekanda-Trepka, 2005, p. 53).

The end of the 1920s was a period when people who were convinced that the development of the Kraj programme could result in ending conflicts and bringing reconciliation between the nations in the Kraj, united around Przeglad. For Abramowicz and his followers, the ultimate goal was to achieve the political independence of the Kraj in one form or another, and to have its fate decided by the representatives of all the indigenous nations. However, this required a constant struggle against radical nationalism. Ludwik Abramowicz felt obliged to "overthrow the barbaric principle that the nation is the supreme good because nationalism founded on this basis justifies all violence and harm" (Abramowicz, 1927, p. 2). His hopes were backed up by the change in newspapers' ownership: in 1928, the magazine became the property of its supporters. Abramowicz nurtured great hopes that the established enterprise would become the beginning of the creation of a great camp of the supporters of krajowość (Nekanda-Trepka, 2005, pp. 53-54).

\section{Krajowość as a Local and Universal Problem}

But the circle of supporters of the idea of krajowość always was and remained small. The vast majority of the local Polish public opinion perceived the Vilnius Region as an integral part of the Polish state. However, thanks to the publications of Przeglad Wileński, the idea of krajowość remained the subject of a heated public debate.

Ludwik Abramowicz repeatedly had to explain the meaning of krajowość ${ }^{12}$ and, according to him, it was Przeglad as the first "Kraj" periodical where the basic principles

12 He presented its phenomenon in the articles "In hoc signo vinces!" [Under This Sign Thou Shalt Conquer!] (1925, no. 13), "Progres" [Progress] (1925, no. 21), "Krajowość i regionalizm” [Krajowość and Regionalism] (1926, no. 11), "Demokratyzm i nacjonalizm" [Democratism and Nationalism] (1931, no. 6-7). In March 1936, he published an article on the occasion of the 30th anniversary of the public appearance of the idea of krajowość. 
of krajowość were formulated. They comprised the separateness and independence of the Belarusian-Lithuanian Lands and the equality of all nations of the Kraj. Describing the contribution of Przeglad Wileński, Ludwik Abramowicz stressed that the pre-war journal's vision of krajowość did not take into account the "historical element" but tried to develop krajowość only "from the point of view of an unconnected democratic doctrine". The post-war Przegląd Wileński corrected this error, finding the sources of krajowość in history. The history of the Grand Duchy of Lithuania was of particular importance for the formation of this concept, as "the feeling of a common state constantly prevailed over the decentralist aspirations and internal antagonisms that were seen here and there" (Abramowicz, 1936, p. 2).

How important the idea and the newspaper promoting it was to Abramowicz, was further proven by the situation in the 1930s, particularly difficult for the newspaper. The number of subscribers was decreasing and the financial situation was worsening. To save the paper, in December 1931 Ludwik Abramowicz moved the editorial office to his own flat at 6 Sierakowskiego Street (today Zerakausko g.) in Vilnius. Later on, in the second half of the 1930s, when Ludwik Bociański, a supporter of the assimilation policy, became governor of the Vilnius province, Abramowicz's periodical went under strict censorship. According to Maria Nekanda-Trepka, in the last years of the newspaper's publication, every second issue did not reach the readers because of censorship. Ludwik Abramowicz appealed to court, but it was not often that he won lawsuits (Nekanda-Trepka, 2005, p. 55; Wojtacki, 2016, pp. 143-145).

In October 1938, due to the illness of the editor, Przeglad Wileński ceased to be published. Its closure reverberated. Even those who had fought against Abramowicz's ideas regretted it. For example, Stanisław Mackiewicz compared the closure of Przeglad Wileński to the funeral of all the "local people" (Nekanda-Trepka, 2005, p. 55).

The story of Przeglad in the 1930s, then, shows that Abramowicz's efforts were not in vain. Even if the idea of krajowość was not supported by masses and became an unsuccessful project, in the 1920s and 1930s Przeglad Wileński was a unique phenomenon in the history of the press in Poland of the time. This fortnightly magazine became a genuine platform for the condemnation of the state policy of national oppression.

\section{Conclusions: The Legacy of the Last Citizen}

\section{Ludwik Abramowicz died in March 1939.}

The spring of that year was turbulent. The spirit of war was in the air but the death of the editor of Przeglad Wileński did not pass unnoticed. The most popular newspapers in Vilnius published obituaries. Kurier Wileński presented Ludwik Abramowicz as an uncompromising man who rejected all "life opportunism" and was fighting for the idea of krajowość until the last moment of his life (Ludwik Abramowicz nie żyje, 1939, p. 1). 
To sum up Römer's opinion on Abramowicz, I evoke a large quotation from the text he wrote in his Dziennik [Journal] on the day of Abramowicz's death:

He was a journalist of exceptional talent, his writing was excellent and sharp. Until the end usque ad finem ${ }^{13}$ - he remained faithful to the so-called Kraj position that was based on the Lithuanian statehood of the Great Lithuania, which united in its bosom the lands of the ethnographic Lithuania and Lithuanian Ruthenia with the capital in Vilnius. He had the courage to face up to the Polish nationalism and the Polish statehood in the historical Lithuanian lands. This was all the more difficult for him as he was personally Polish but first of all he was a Vilnius citizen and a son of Lithuania, not of Poland as such. But Ludwik Abramowicz was a man with temperament and the otherness of his ideological stand and the unpopularity of his political beliefs in the Polish opinion not only did not intimidate him or make him resign but rather excited him and incited his resistance. He walked like with his eyes fixed on the star of his idea. (Römer, 2017-2018, vol. 6, pp. 25-26; entry dated 10 March 1939)

And one year after his death, the person of Ludwik Abramowicz and his views proved to be greatly needed by the Polish community of Vilnius. To a great extent, the interest in his legacy was not only a tribute to him but also a result of the new geopolitical situation which occurred in October of 1939, when Stalin handed Vilnius over to Lithuania. For the local Polish community, the restoration of Vilnius as the capital of the Republic of Lithuania made the idea of krajowość topical again.

On the occasion of the first anniversary of the death of Ludwik Abramowicz, one of the main ideologists of the idea of krajowość, a solemn commemoration was held in the Vilnius Public Library on 10 March 1940. In the presence of Deputy Prime Minister of Lithuania, Kazimieras Bizauskas, representatives of almost all the nations of the Belarusian-Lithuanian Lands appeared. On the same day, the Vilnius Gazeta Codzienna [Daily Gazette] gave the opportunity to well-known columnists to present the figure of Abramowicz and his ideological legacy in its pages. The newspaper published various statements, but the reflections of Ludwik Abramowicz's daughter, Zofia, ${ }^{14}$ were among the most interesting ones. A lecturer at the Stefan Batory University, she noted that for a group of supporters of the position of Kurier Wileński and Stowo, krajowość was only a method or means of domination of the Polish nation, while for Przegląd Wileński it remained an aim.

This is how, according to the daughter, her father's standpoint looked:

Because no nationalist, as he declared, can accept krajowość for it is necessary that national
ideas - by their very nature requiring exclusivity - should yield to the idea of krajowość, which
is the opposite of exclusivity and the embodiment of community. Therefore, it is unnecessary
in a nationally homogeneous state but necessary in a multi-ethnic state, the Grand Duchy
of Lithuania, in which all three nationalities will be at home and will exercise completely
equal rights, following the example of Belgium or Switzerland. The capital of such a state

13 Until the end (Latin).

14 After the war, Zofia Abramowiczówna worked at the Nicolaus Copernicus University in Toruń (Bibik \& Kola, 2019, pp. 329-334). 
will then be Vilnius, which will finally abandon the role of a pawn whose future is decided by someone else according to the nationalist demands of this or that side.

In turn, any absolute striving for political and cultural hegemony, be it of the Polish, Lithuanian or Belarusian element, must necessarily split up this unity because the result would then be the relegation of the other elements to the role of a "minority" which is tolerated, allowed to do this and that - but the more or less liberal system of government by the privileged majority would be of no significance because the completely separate character of this statehood, which our lands require due to their ethnic and cultural diversity, would be broken. (Abramowiczówna, 1940, p. 3)

Yet, Zofia Abramowiczówna saw no chance for the idea of krajowość in the near future: "The idea of krajowość is likely to remain unpopular for a long time, like any idea which demands that national egoisms be restrained and certain immediate and seemingly great benefits be renounced for the sake of the greater whole". According to her, in the new geopolitical situation, the Krajowcy should remain in opposition because the concept of Vilnius as the capital of the nation-state is unacceptable to them. To tell the truth, for her it was possible that the situation might change when the Lithuanians themselves understood that the Pahonia emblem was not identical with the Lithuanian national symbol, and that restoring Vilnius as the capital would require a revision of certain foundations of the Lithuanian statehood.

Römer, who also published a piece on Abramowicz in the issue of Gazeta Codzienna, placed similar hopes in the Vilnius Krajowcy and the Lithuanian state. He emphasised that the ideology of krajowość juxtaposed the supporters of "kresy" doctrine with the concept of Lithuania as a country with its own political autonomy. According to him, the Lithuanian statehood of that time was exactly the fullest embodiment of this autonomy: "There is no other Lithuania but Lithuania". According to Römer, krajowość will only have a chance if the Krajowcy of Vilnius "feel the words of the living Lithuanian land" and work for the statehood of Lithuania (Römer, 1940, p. 3).

Another contributor to this issue of Gazeta, Józef Mackiewicz (1902-1985), Stanisław's brother, associated with Stowo, disagreed with Römer, noting that Abramowicz's ideal was Lithuania within different borders, with a population that was heterogeneous in terms of nationality, with a different political "physiognomy", whose "internal and external structure" would correspond to different concepts of statehood (Römer, 1940, p. 3). Józef Mackiewicz doubted whether the Lithuanian statehood corresponded with Ludwik Abramowicz's ideal.

In conclusion, in the interwar period the idea of krajowość was quite actively present in the social life of the Vilnius Region. Krajowość was a certain ideological response of both liberal-democratic and conservative circles of the Polish community of the Vilnius Region to the absolute assimilation policy of the Polish central and local authorities. And the traditions of the pre-war Krajowcy were most clearly reflected in the publications of Przeglad Wileński. Ludwik Abramowicz unwaveringly defended the idea of the political independence 
of the Belarusian-Lithuanian Lands and the decision of its future by the representatives of indigenous nations, which met with accusations of "national treason" both from the administration and the Catholic Church as well as from the local Polish majority. At the same time, the newspaper became a platform that informed the Polish public opinion about the problems of national life of the Kraj through publications by activists of the Belarusian and Lithuanian movements and representatives of the Jewish community.

The life and activity of Ludwik Abramowicz show that despite all political and national-cultural realities, the idea of krajowość as an idea of harmonious coexistence of the nations of the historical Lithuania was popular and found new supporters, who honourably called themselves "citizens of the Grand Duchy of Lithuania". However, very often the adjective "last" was added to this honorary title.

\section{References}

\section{Archival sources}

Abramowicz, L. Korespondencja i dokumenty, Fond 79-31, The Wróblewski Library of the Lithuanian Academy of Sciences.

Römer, M. (1912). Dziennik, Vol. 2, The Wróblewski Library of the Lithuanian Academy of Sciences.

Römer, M. (1914). Dziennik, Vol. 4, The Wróblewski Library of the Lithuanian Academy of Sciences.

\section{Print Sources}

Abramowicz, L. (1911). Bez drogowskazu. Przegląd Wileński, 1911(Trial issue), 3-5.

Abramowicz, L. (1912). Po wyborach wileńskich. Przegląd Wileński, 1912(41-42), 1-3.

Abramowicz, L. (1913a). Stanowisko krajowe a idea narodowa. Przegląd Wileński, 1913(1314), 1-3.

Abramowicz, L. (1913b). Wpływy postronne. Przegląd Wileński, 1913(22-23), 1-3.

Abramowicz, L. (1920). Artykut redakcyjny. Gazeta Krajowa, 1920(1).

Abramowicz, L. (1921). Reakcja. Przeglą Wileński, 1921(1), 1-2.

Abramowicz, L. (1923). Po dwóch latach. Przegląd Wileński, 1923(18), 1-2.

Abramowicz, L. (1925). In hoc signo vinces! Przegląd Wileński, 1925(13), 1-2.

Abramowicz, L. (1927). Bez skrupułów. Przegląd Wileński, 1927(1), 1-2.

Abramowicz, L. (1936). Trzydziestolecie ideologii krajowej. Przegląd Wileński, 1936(5), 1-2.

Abramowiczówna, Z. (1940, March 10). Kilka słów o idei krajowej. Gazeta Codzienna, 56.

B. H. [Abramowicz, L.]. (1915). Polskość na Litwie. Myśl Polska, 1915(4), 46-47. 
Bardach, J. (1988). O dawnej i niedawnej Litwie. Wydawnictwo Naukowe UAM.

Bibik, B., \& Kola, A. (2019). Mistrzynie: kobiety w Uniwersytecie Mikołaja Kopernika w Toruniu: Przypadek Zofii Abramowiczówny. Nauki o wychowaniu. Studia Interdyscyplinarne, 8(1), 329-334. https://doi.org/10.18778/2450-4491.08.25

Bielski, A. S. (1931). W poszukiwaniu nowych dróg. Przegląd Wileński, 1931(6-7), 5-7.

Gierowska-Kałłaur, J. (2007). Polacy i Białorusini we wzajemnych opiniach w latach 1918-1921. Studia z dziejów Rosji i Europy Środkowo-Wschodniej, 2007(42), 35-66.

Hal, J. (1929). Nastroje i kierunki polityczne w społeczeństwie żydowskim. Przegląd Wileński, 1929(18-19), 12-13.

J. H. (1931). Walka o język żydowski w szkole. Przegląd Wileński, 1931(4-5), 11-12.

Januszkiewicz-Jurkiewicz, J. (2010). Stosunki narodowościowe na Wileńszczyźnie w latach 1920-1939. Wydawnictwo Uniwersytetu Śląskiego.

Jurkiewicz, J. (Ed.). (1999). Krajowość - tradycje zgody narodów w dobie nacjonalizmu: Materiały z międzynarodowej konferencji naukowej w Instytucie Historii UAM w Poznaniu, 11-12 maja 1998. Instytut Historii UAM.

Kon, P. (1928). Numerus nullus. Przeglad Wileński, 1928(15), 5-6.

L. A. [Abramowicz, L.]. (Ed.). (1918). Litwa podczas wojny: Zbiór dokumentów, uchwat i t. p. Wydawnictwo Departamentu Spraw Politycznych.

L. A. [Abramowicz, L.]. (1928a). Dzień rozwagi. Przegląd Wileński, 1928(17), 1-2.

L. A. [Abramowicz, L.]. (1928b). Wilno a legiony. Przegląd Wileński, 1928(15), 2-3.

L. A. [Abramowicz, L.]. (1929). Po zgonie Czesława Jankowskiego: Garść wspomnień. Przeglad Wileński, 1929(18-19), 8-9.

Lit. (1928a). Idea krajowości (I). Kurier Wileński, Nowogródzki, Grodzieński, Suwalski, Poleski i Wołyński, 1928(10), 1.

Lit. (1928b). Idea krajowości (II). Kurier Wileński, Nowogródzki, Grodzieński, Suwalski, Poleski i Wołyński, 1928(11), 1.

Lit. (1928c). Idea krajowości (III). Kurier Wileński, Nowogródzki, Grodzieński, Suwalski, Poleski i Wołyński, 1928(12), 1.

Lit. (1928d). Idea krajowości (IV). Kurier Wileński, Nowogródzki, Grodzieński, Suwalski, Poleski i Wołyński, 1928(17), 1.

Ludwik Abramowicz nie żyje. (1939). Kurier Wileński, Nowogródzki, Grodzieński, Suwalski, Poleski i Wołyński, 1939(69), 1.

Mackiewicz, S. (1939). Ś.p. Ludwik Abramowicz. Słowo, 1939(68), 1.

Miknis, R. (2008). Mikhal Romèr (1880-1945): Shtrykhi da palitychnaĭ biiahrafii kraëŭtsa. Homo Historicus, 2008(1), 236-260.

Miknys, R. (2000). Problem kształtowania się nowoczesnego narodu Polaków litewskich w pierwszej połowie XX w. Biuletyn Historii Pogranicza, 2000(1), 21-32.

Miknys, R. (2001). Wileńscy autonomiści i ich projekty autonomii politycznej Litwy w latach 1904-1905. Lituano-Slavica Posnaniensia, 2001(8), 97-113. 
Nekanda-Trepka, M. (2005). Ludwik Abramowicz-Niepokójczycki: Redaktor Przeglądu Wileńskiego. In T. Bujnicki \& K. Stępnik (Eds.), Ostatni obywatele Wielkiego Księstwa Litewskiego (pp. 49-59). Wydawnictwo Uniwersytetu Marii Curie-Skłodowskiej.

Od redakcji. (1914). Przegląd Wileński, 1914(9-10), 1.

Ponarski, Z. (1998). Konfederacja Wielkiego Księstwa Litewskiego 1915-1916. Białoruskie Zeszyty Historyczne, 1998(10), 56-67.

[Römer, M.]. (1906, February 28). Od redakcji. Gazeta Wileńska, 1.

Römer, M. (1929a). Reforma konstytucyjna litewska. Przegląd Wileński, 1929(2), 3-5.

Römer, M. (1929b). Reforma konstytucyjna litewska. Przegląd Wileński, 1929(3), 2-4.

Römer, M. (1929c). Reforma konstytucyjna litewska. Przegląd Wileński, 1929(4), 2-4.

Römer, M. (1929d). Uniwersytet litewski w Kownie. Przegląd Wileński, 1929(20-21), 7-10.

Römer, M. (1930). Reforma Uniwersytetu w Kownie. Przeglad Wileński, 1929(13-14), 8-10.

Römer, M. (1934). Kłajpeda jako element solidaryzmu Bałtyckiego. Przegląd Wileński, 1934(7-8).

Römer, M. (1940, March 10). Nie ma Ludwika Abramowicza. Gazeta Codzienna, 1940(56).

Römer, M. (2017-2019). Dzienniki (G. Nowik, Ed.; Vols. 1-6). Karta.

S-icz. (1934). Rozmowa z Mińczukiem. Przegląd Wileński, 1934(18-19), 3-6.

Sawicki, J. (1998). Michał Römer a problemy narodowościowe na ziemiach byłego Wielkiego Księstwa Litewskiego. TNT.

Skarga Litwinów Wileńskich (Memoriał Komitetu Litewskiego w Wilnie, złożony Nuncjuszowi papieskiemu w Warszawie). (1928). Przegląd Wileński, 1928(9), 2-4.

Smalianchuk, A. (2004). Pamizh kraiovastsiu i natsyianal'naĭ idèiă: Pol'ski rukh na belaruskikh i litoŭskikh zemliakh: 1864-liuty 1917 h. Neŭski prastsiah.

Smalianchuk, A. (2017). "Kraiovaia idèia" ŭ belaruskaĭ historyi. Vydavets Zmitser Kolas.

Smalianchuk, A. (2018). Raman Skirmunt (1868-1939): Zhytstsiapis hramadzianina Kraiu. Vydavets Zmitser Kolas.

Solak, Z. (2004). Między Polska a Litwa: Życie i działalność Michała Römera: 1880-1920. Wydawnictwo Arcana.

Swiencickyj, J. (1930a). Metropolita Andrzej Szeptycki jako działacz społeczny i narodowy. Przeglad Wileński, 1930(5), 3-4.

Swiencickyj, J. (1930b). Metropolita Andrzej Szeptycki jako działacz społeczny i narodowy. Przegląd Wileński, 1930(6), 5-6.

Szpoper, D. (2009). Gente Lithuana, Natione Lithuana: Myśl polityczna i działalność Konstancji Skirmuntt (1851-1934). Arche.

Vigilans. (1930). Szermierze o język białoruski w Kościele katolickim. Przegląd Wileński, 1930(6), 4-5.

W. S. (1931). Wyprostowana linja. Przegląd Wileński, 1931(4-5), 5-7. 
Wojtacki, M. (2016). Represje administracyjne wobec Przeglądu Wileńskiego Ludwika Abramowicza w latach trzydziestych XX wieku: Przyczynek do polityki prasowej obozu pomajowego. Zapiski Historyczne, 81(3), 129-150.

Za wschodnią ścianą. (1930). Przegląd Wileński, 1930(6), 1-2.

Ż. A. T. (1929). Ciężka sytuacja ludności żydowskiej. Przegląd Wileński, 1929(5-6), 14-15.

\title{
Ostatni obywatel Wielkiego Księstwa Litewskiego. Wprowadzenie do biografii redaktora Ludwika Abramowicza (1879-1939)
}

\begin{abstract}
Abstrakt
Publicysta i redaktor Ludwik Abramowicz był jednym z głównych ideologów idei krajowej w jej liberalno-demokratycznej wersji. Bronił zasad krajowości nawet w dwudziestoleciu międzywojennym, kiedy w Polsce dominowała polityka asymilacji mniejszości narodowych, a stosunki z Litwą miały charakter zimnej wojny. Dzięki Abramowiczowi „Przegląd Wileński" (1921-1938) stał się ostatnim bastionem idei krajowej, czynnie popularyzując ją w życiu publicznym Wileńszczyzny. Abramowicz konsekwentnie bronił idei politycznej niezależności Kraju Białorusko-Litewskiego i decydowania o jego losie przez przedstawicieli wszystkich rdzennych narodów. Życie i twórczość Abramowicza, publikacje w „Przeglądzie Wileńskim” świadczą, że wbrew wszelkim realiom politycznym i narodowo-kulturowym idea krajowa jako idea harmonijnego współistnienia narodów historycznej Litwy cieszyła się popularnością i znajdowała nowych zwolenników.
\end{abstract}

Słowa kluczowe: ruchy narodowe na początku XX wieku; „idea krajowa”; tolerancja; „Polacy litewscy”; historyczna Litwa; Ludwik Abramowicz; „Przegląd Wileński”

\section{Citation}

Smalianchuk, A. (2021). The last citizen of the Grand Duchy of Lithuania: The editor Ludwik Abramowicz (1879-1939) and the idea of krajowość. Sprawy Narodowościowe: Seria nowa, 2021(53), Article 2584. https://doi.org/10.11649/sn.2584 